\title{
Social Movements in Tunisia and Egypt: A Tale of Two Revolutions
}

\author{
Abdesselem Mahmoud ${ }^{1}$ \\ ${ }^{1}$ Carthage University, National School of, Architecture and Town Planning, Tunis, Tunisia \\ Correspondence:Abdesselem Mahmoud, Carthage University, National School of, Architecture and Town Planning, \\ Tunis, Tunisia.
}

Received: January 12, 2015

Accepted: January 26, 2015

Available online: March 13, 2015

doi:10.11114/ijsss.v3i3.718

URL: http://dx.doi.org/10.11114/ijsss.v3i3.718

\begin{abstract}
In this paper, the author addresses the Arab uprisings both in Tunisia and Egypt. He tries to explain to which extent the so called Arab Spring is amongst social movements which joins in global ones related to capitalist world system and to its local allies authoritarian regimes in Middle East and North Africa.

Those new social movements could be explained by people outrages due to social inequalities, injustices, and human rights abuses. The uprisings are triggered by outrages and hopes for better society. They are wireless because they were fuelled and framed by new media (Internet, Face Book, Twitter), leaderless in the sense that they sparked collectively and without any ideology, religion, or leader.

The study theoretical framework draws from literature's review on the issues of World System (Wallerstein 1970s), the concept of power according to: (Max Weber 1978; Michel Foucault 1984; Jürgen Habermas 1991; Craig Calhoun 1992; Seyla Ben Habib 2012; Nancy Fraser 1990s and others). In order to better understand the social movements in Arab World, the author used the concept of System, Actors, Emotions, Strategies, opportunities, and contexts.

Finally, the objective of this research is explain to which extent Arab uprisings are in fact social movements linked to the social and political changes in Arab societies in the arena of wider global social movements.
\end{abstract}

Keywords: Egypt, Revolutions, Social Movements, Tale, Tunisia

Addressing social movements is in the core of social sciences preoccupations. Our starting point in this study of social movements in Tunisia and Arab societies is: to which extent those movements are parts of local revolutionary movement or they are triggered by other supranational and global factors at work in Tunisia's social changes. Moreover, what matters is not movement per se but their direct and indirect impacts on societies where they occurred and grown. In short, our case study is the so-called 'Arab Spring'. Is it a revolution or new social movements?

Our theoretical framework encompasses literature review on the social movements in the world, in Arab societies and in Tunisia. Our readings on the world system (Wallerstein 1970s, 2012) power and counter powers (Weber, 1978; Foucault 1984; Bourdieu 2013; Habermas 1991; Calhoun1992; Ben Habib 2012; Fraser 1990 to cite but a few) about public sphere, civil society and wireless media networks (Castells 2006, 2012) help us to better understand the so-called "Arab Spring' uprisings.

Our method is theoretical based on peer reviewed and not peer-reviewed papers published in Reviews and journals. We also read some books written on the topics of social movements, public sphere, wireless media, and civil societies. We also consulted some reports, and empirical researches findings published by myriad of scholars, world organizations, and academia on the topic. The concepts of system, organization, institutions, actors, strategies, and opportunities constitute, somehow, our main tools of analyzes which should be verified within ritual interactions in local culture of Arab societies.

\section{Context and Actors of Social Uprisings}

Injustice entails anger and protests against its doer. Social movements didn't occur by pure hazard. They had their implicit and explicit causes in history, politics, society, economy, and culture. In fact, they are narrowly linked to human being, and are anthropogenic. Thus, there is no space regardless of time and movement. Social movements were traditionally approached as class struggles (Marx and Engels 2002).

According to Marxist approach of social movement, the working class is the main actor of those movements. However, contemporary social movements are also propelled by other excluded social groups such as blacks, emigrants, pupils, students, women, unemployed youth, and so on. Mac Nally et al. argued: "In the wake of events of 1968 and the rise of ecological, feminist, and peace movements during the 1970s, a growing chorus come to argue that structural changes 
society, politics, and economy were displacing "the working class as a key factor in social transformation" (Nally 2013: 5). Any movement triggers and grows within and against the world system in crises (Wallerstein 2012: 9).

Since sixties, new social movements had been growing. They were not propelled only by labor classes, but also fuelled by excluded groups such as blacks in America, immigrate people in industrial societies, students, unemployed, women, and so on. The protestors contest consumption capitalist society, which involved their alienation, and over repression through police, army, media apparatuses used by capitalist state to crack down any protest, or revolution. We are here in presence of new phenomenon displaying myriad of actors participating in those movements bypassing state institutions. They have their positive and negative effects on the latter. Positive when they begot changes of the incompatible and invaluable laws, rules organizing social life, and giving new relevant ones. Otherwise, they could be irrelevant and non plausible, when they target institutions in order to weaken and destroy them without proposing more relevant ones instead.

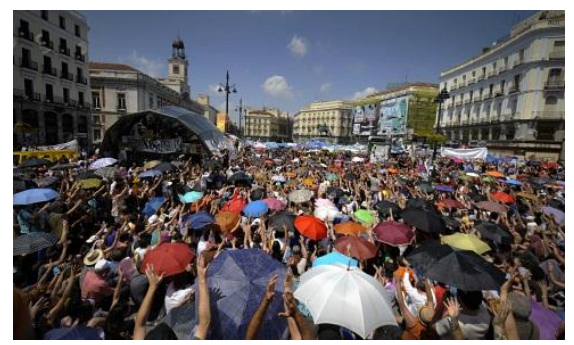

Protesters on the Puerta del Sol in Madrid in October 15, 2011: young people camped in main squares across Spain to protest against economic austerity. Photograph: Pedro Armestre/AFP/Getty Images

http://www.theguardian.com/commentisfree/2011/oct/29/spanish-protests-occupy-people-together retrieved on Sunday, December $7^{\text {th }}, 2014$ at 10

In fact, contemporary, social movements have their grassroots in a networked society of flows and goods. They are leaderless and generally without any preexisting ideological system. Neither political parties, nor religious sects are behind social uprisings, which occurred worldwide. Though, information and communication networks (e.g., Internet, Facebook, Twitter) are the main channels and tools of those protests and uprisings movements (Castells 2009, 2012). In Tunisia (December, 17, 2010s, January, 14, 2011), Iceland (October 2008-January 2009), Spain(2011) Wall Street(USA 2009), umbrella occupy movement in Hong Kong November, 2014,Cairo ( Tahrir square, 2011 against Mubarak regime, Morsi,(2013) Yemen, Bahrain, Libya, Syria, Algeria,(2011, 2014) and more sparked generally against authoritarian regimes. Though, in Iceland, Spain, USA, and somehow in Algeria they are pluralistic parliamentarian regimes. Other factors were the social movement grassroots (i.e., emotion, economic downturns).

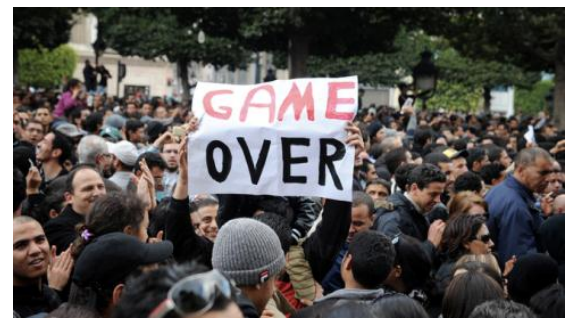

Tunisian People Protest in HabibBourguiba Avenue,January 14, 2011

http://www.google.fr/imgres?imgurl=http://abdes.e-monsite.com/medias/images/manifestations-a-tunis-le-14-janvier-2011-1.jpg\&im grefurl=http://abdes.e-monsite.com/pages/revolution-tunisienne/ \&h=371\&w=658\&tbnid=3GcmwenVfTNvQM:\&zoom=1\&tbnh=90 \&tbnw=160\&usg=_uH-xFp0hrpGAo2U9nZh-joDnYRc=\&docid=yyikfeSGdb3_bM\&sa=X\&ei=bwJ7VIruFMXWapnjAg\&sqi=2\&v ed=0CCMQ9QEwAA\&dur=2528 retrieved on Sunday, November, 30, 2014 at 12:43

\subsection{Against Globalizing Capitalist System?}

Is it a hazard, that uprising begun in Tunisia 2008, in miner basin of Gafsa in the south east of Tunisia? Remark, the first French company of phosphate deposit extraction "Sfax-Gafsa was created in 1897 by colonial state. It was a stage of protests against unfair youth unemployed recruitment in the company in 2008.

At a time when the Lehmen and Brothers' Bank collapsed due to financial crash, which impacted on banks networks worldwide, Tunisian economy was not shielded from the financial downturn. Moreover, outrage and hope could also explain the 'Arab uprising'. Lina Khatib et al. argued: "Diasporas also played a key role in political activism, particularly in the most repressive political regimes. In Tunisia, Libya, and Syria, organized activism was relegated to groups played an important role in highlighting the political repression within the country and providing some activists an exit option when their condition inside the country became unsustainable."(El Khatib, 2014: 4). 
The authoritarian regimes in Arab societies succeeded, somehow, during a long period to make their hegemony accepted by wide ranges of middle classes when the latter found opportunities to negotiate interests, power, and allegiance with the rulers (Ben Romdhane 2010s; Hibou 2006; Geisser and Camau 2003). Submission and resignation became trivialized for people whose human rights, civil freedoms were confiscated by a regime, which scattered fear among its subjugated people. Some, opposition elite dared to challenge regime authoritarianism, but they are generally reduced and silenced by arrests and imprisonment.

Since January 26, 1978, Ben Ali had been giving an impression of a strong state man who cracked down protests led by the main trade unions, and accessed to presidency of the state through a white medical coup against his former president HabibBourguiba.

Regime change required the alignment on the neo liberal capitalism in economy and society. The Ben Ali regime had to apply the Structuring Adjustment Plan in Tunisia in order to restructure local economy accordingly to the globalized world and to the main financial institutions (e.g., World Bank, IMF, European Union banks). In the beginning of its access to power, Ben Ali had allegedly approved some human rights, authorized some associations, organizations, political parties. The regime succeeded, somehow, to rule and ensured social stability by dealing with social uprising by social regulation implemented by government, employee's and employers' unions (i.e., UGTT, UTICA, UNA) ${ }^{1}$

This type of top down 'governmentality' (Foucault 1997) ${ }^{2}$ was in favor of a growing upper middle classes benefitting of a liberalized economy fostering consumption, loans, and indebtedness for acquiring lands, social facilities, and luxury consumptions. People dealt and negotiated obedience and allegiance with the regime in day-to-day life. Cronyism, corruption and authoritarianism were so growing that anger developed amongst people and revolution sparked. Was it explainable by the ambulant merchant Mohamed Bouazizi self-immolation? We cannot see the wood for the trees. Thus, it was a traumatic event, which triggered protests all over the country. Demonstrations erupted first in Gafsa (2008), in Ben Guerdane (2010s), Sididi BouZid (2010s). How a singular act committed by an individual entailed the regime change? Structure nexus agency (Giddens 2013) is worth to explain this social change, but not enough. Information played a key role in those uprising, which Manual Castells explained as Networks of outrage and hopes. Then, emotion and cognition are worth in understanding those uprising as social movements.

\section{Social Movement or Revolution of Hope?}

Some psychological and cultural factors played a key role in the Arab uprising. Pride, bravery, dignity, freedom, and many ethical values rooted into Arab culture didn't disappear despite the modernization process of Tunisia society. The notion of Futuwwa (virility), muruwwa(generosity), Bravery, kinship (IbnKhaldoun 1969, Zghal 1982) remained and regenerated within collective memory of young Tunisian in the Diaspora and in homeland who upraised against authoritarian regime. The neuroscience (Jeff Goodwin, James M. Jasper 2009, Clark 2012; Francesca Polletta1 and James M. Jasper2, 2001; Davidson et al.) is worth for better understanding contemporary social movements. Bur note: those social movements are global and local in a networked society of information flows and nodes (Castells 2006; Sassen 2013). In order to better understand the emotion and cognition as triggers and stressors of social movement, we seek the human body and brain interaction with the surrounding physical space.

The body is not defined regardless of its actions, reactions, and interactions' mechanism within the world of objects, species and others human beings. Its interaction is both corporal and symbolic. People interact with their surrounding natural and build environment. The neurologic system plays a key role in space cognition through centripetal and centrifugal movements. Human brain is focal locus of those interactions and cognitive space embodiment and representation. In fact, a close link exists between body, space and mind. In his writing on psychology of space Abraham Moles demonstrated how, as a shell, space is both content and container. From skin to clothes, room, house, quarter, city, region and the world and vice versa, a physical and symbolic interaction exists and shapes our space's shell. (Moles 1978) Furthermore, neurosciences are worth in understanding urban space.

As far as affect disorder is concerned, Davidson, and colleagues (Davidson et al. 2000a) argued that-variousmyriads ofdisorders of affect could be characterized as "disorders in context regulation of affect". According to Davidson and his colleagues: "fear that may be appropriate in response to an actual physical threat but persists following the removal of that threat, or sadness that may be appropriate in the acute period following a loss but persists for a year following that loss, are both examples of context-inappropriate emotional responding. In these examples the intensity and form of the emotion would be perfectly appropriate in response to the acute challenges, but when they occur in the absence of those acute stresses they can be viewed as context-inappropriate. » (Davidson, 2000)

${ }^{1}$ Union Générale des Travailleurs Tunisiens; Union Tunisienne de 1'Industrie du Commerce et de 1'Artisanat; Union Nationale des Agriculteurs

${ }^{2}$ Foucault coins the concept of "govern mentality" as a "guideline" for the analysis he offers by way of historical reconstructions embracing a period starting from Ancient Greece through to modern neo-liberalism (Foucault 1997b, p. 67). 
There is also a cultural layer, which grows on the prefrontal and dorsa lateral cortex. The space is not only conceived as a form and content in geometric way. It is, also, perceived as a physical reality we touch, smell, see, hear and taste. The space is also lived in day-to-day life with our affects, feelings, emotions, and representations (Lefebvre1968)

Many feelings of hope, anger, joy, happiness, sadness, outrage, and disdain constitute depressors and triggers of uprisings and protests when, in favorable contexts, actors find opportunities to act. Social movements occurred usually due to outrages and hopes. The information network plays a key role in triggering stressors. TV channels, Face book, Twitter, mobile phones were main tools of communication between repressed people by dictatorships. When some of those bloggers dared to broadcast their defying challenges against authoritarian regimes, they succeeded to break the wall of fear (Chaudry 2014) built by the rulers in order to dominate and oppress their ruled people. In fact, modern social movements are global, leaderless, collective, and virtual before occupying streets (Castells 2012).

When people are gathering in the streets was banned by authoritarian regimes, young powerless people found new social networks, wireless media as the most suitable tool to communicate despite cyber police control. Hence, they overcome the state of fear established and scattered among them. Then, occupy streets (e.g., Bourguiba Avenue, Casbah, Menzah dome, Bardo place, and all over Tunisian homeland. Those spaces become commonplaces for protests. It is phenomenon witnessing a development of the self and a quest of a new togetherness in public spaces used to be monopolized by state authority.

After the election of October, 23, 2011, the Trö̈ka coalition of the winning parties committed many mistakes: the neglect and even refusal of any opposition to its policy, the lethargy, non punishment, and laxness towards Salafist movements which entailed the infiltration and activities of terrorists in borders areas through Libya and Algeria. The terrorist acts had been growing: murder of LotfiNaqdh, Senior coordinator of Nidaa Tunis Party in Tataouine South East of Tunisia, assassination of Patriotic Democratic Leader ChokriBelaïd, February, 6, 2012, killing of Mohamed Brahmi, People Movement Leader and representative in the ANC, July, 25, 2012, some security and army agents were killed by terrorist groups. Those acts heated political life and entailed the resign of the first Troikka government Prime Minister and the second one led by Ali Larayedh former interior minister.

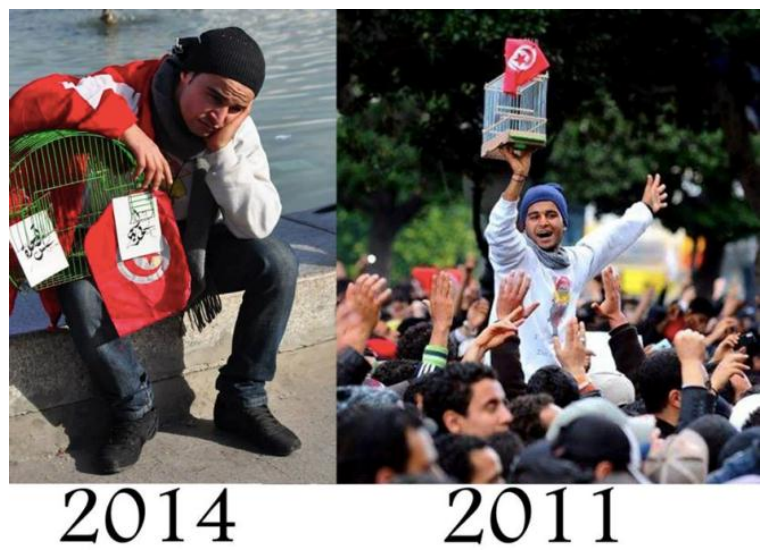

The same young Tunisian protestor's feelings in January, 14, 2014 and in to date

Disappointment after hope

Civil society moved on and occupied places: HabibBourguiba Avenue, Kasbah, and Bardo places. This movement was growing along with debate and controversies over the new constitution: Islamists orthodoxies fought fiercely in order to insert Shariaa laws into the constitution, secularists and civic organizations and associations claimed a constitution that fulfill the revolution objectives: freedom, dignity, and social justice. Finally, both parties succeeded to reach a consensus and approved a constitution, which guarantees the Arab and Muslim belonging of Tunisia and its openness to universal civil rights values. Though, the death penalty was not abolished and some found that limiting constitution to Arab and Muslim belonging could exclude other non-Muslim and non-Arab citizens from full citizenship rights.

In short, the street occupying, the popular movements countrywide under the Troïka elected transitional two governments had shown that only elections are not enough to guarantee a real participative democracy. Moreover, the street movements had the merit to make Islamist representatives accept to achieve the constitution regardless of sharia, the step down of the government, and a national dialogue fostering a democratic transition through fair and free elections by the end of 2014

The wireless social media and independent civil society activists played a key role in the pre and post- revolution periods. The social movements fuelled by these communication networks fostered the people togetherness as spaces of autonomy in virtual and physical spaces.

\section{Social Movements in Tunisia: Places and Flows}


Many presumed that Tunisian revolution was triggered by Mohamed Bouazizi self-immolation, thanks to wireless media (Internet, Facebook, Twitter, and Bloggers), to some radical movements (Islamist, secularists...). All of these presumptions were mere propaganda and don't really express the grassroots of the so-called 'Arab Spring'. Understanding those social movements require more scientific attention. SamiaMihoub argued in this issue: "In the wake of Mohamed Bouazizi self-immolation, "Takriz movement claimed its direct and leading participation in the uprisings. The first video broadcasted on Face Book by Takriz which means fed-up! In December 18, 2010s showed clashes against SidiBouZid local authorities. Afterward, many videos of such had flown on Face Book, Twitter..." (Mihoub, 2006:21). In fact, wireless media and social networks played a key role in the uprising overspread through the country.

The triggers of uprisings in Tunisia go back to miner basin uprising against unfair youth recruitment in Sfax-Gafsa Phosphate Company. Why not wonder how it erupted in 2008 in the mainstream of world financial crisis and economic downturn worldwide? The phosphate extraction began in 1900s in Gafsa southwest of Tunisia and exported to be transformed first abroad and since 1970s in Gabes chemical complex in the South East of Tunisia. Remark, the entire surrounding neighborhood are damaged. The chemical factories seriously affect fauna and flora. Since 1990s, arose the ecological movement in Tunisia.

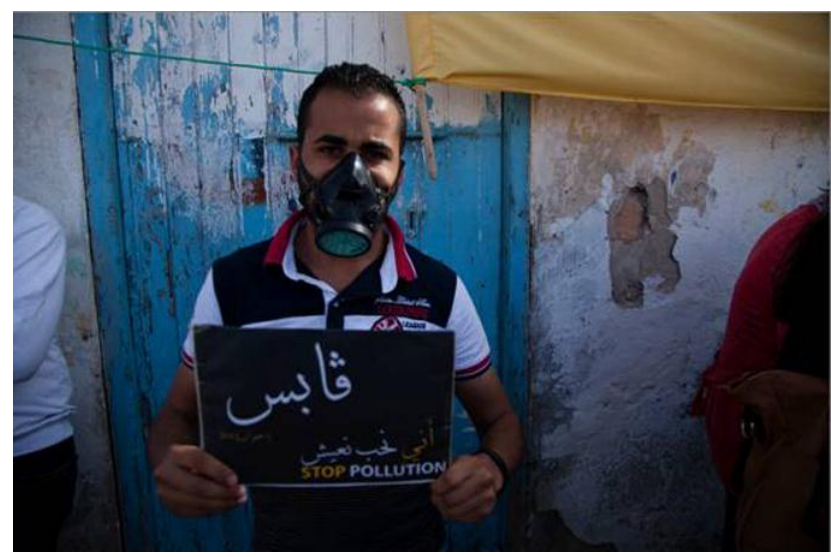

Source:http://2.bp.blogspot.com/8HyIylKCozY/UcMGMy8ElsI/AAAAAAAAAaY/A_cBc5YMPR0/s1600/20136913212752734_20 .jpg retrieved on Friday, December 12, 2014 at 20:08

"I want to live, stop pollution" Gabes(South East of Tunisia)

Crowd is a negation of the self-according to Gustave Le bon analyses, which draw in Freudian psychoanalyses of Unconsciousness self and selfishness characterizing individual who in modern society retire on oneself and avoid crowd and togetherness. Le Bon Thesis focuses on two ambivalent and opposing sticking points of individuals: libido and identification in other words between pleasure principle and reality one or ego and super ego. (Le Bon 1905) From Le Bon, to Freud passing by Tarde: ", the crowd psychology interest shifted from spontaneous and temporary gathering to "artificial crowd", from masse to its leader." (Dupuy, 1992:198) Some affective bond exist within community need a leader. In Tunisia, the ousting of HabibBourguiba by Zine El Abidine ben Ali could be explained by the weakness of the former, but mainly but Tunisian society changes under global market economy logic. The urging forces of internal and external social movements toward much economy liberalizations led to the end of welfare state and thus to charismatic Bourguiba power. Ben Ali regime used Democratic Constitutional Assembly RCD and strong police apparatus to control people in banning crowds gathering and violated civil rights. These ones were only sometimes tolerated under its control. Could we wonder, in this way, free social movements in the aftermath of 'Arab spring' uprising are in quest of a new leader? Do people in Arab countries where occurred those protests lack leaders? Networks of social media played a key role in triggering uprisings. They are wireless and leaderless.

\subsection{Wireless and Leaderless Social Movements}

The term "new social movements" refers to a group of contemporary (or recent) social movements that have played a significant and, for most commentators, largely progressive role in Western societies from the late1960s.

The identification of these waves of activism as "new" typically refers to their concern with issues other than class. The category normally includes peace and anti-nuclear movements, environmental, ecological or green movements, lesbian and gay liberation; second wave feminism, antiracist and alternative lifestyle movements. (Erik Clark, 2012:13).

The nowadays-public sphere is not only expressed and communicated through traditional media (Newspapers, Radio, TV...), it is also transmitted by new wireless media networks (Internet, Face Book, Twitter) constituting some urban and informational nodes of network powers transcending nation-states and local communities worldwide. Talking about the role of media in Occupy Wall Street Clark argued: 
«The disparity in coverage by the traditional media versus social media certainly justifies a point that social media, in terms of coverage of social movements, has become prolific in its abilities as an information source, for communication and organization and creating awareness within the digitized public sphere. »(Clark, 2012: 53)

The authoritarian regimes in the Arab World opened economy and society to the foreign investment and neo liberal capitalism but they restrained, and strangled expression freedom and violated civil rights. In Egypt, the blogger KhaleedSaïd launched a campaign against Hosni Mubarak Regime. He was arrested and killed. « By 2005, Egypt was home to a thriving and diverse blogosphere of committed and insightful thriving and diverse blogosphere of committed and insightful political commentators who began to challenge the narrative of the state-run media, uncovering major stories that the state-controlled sector either couldn't or wouldn't run (Eaton, 2011a).

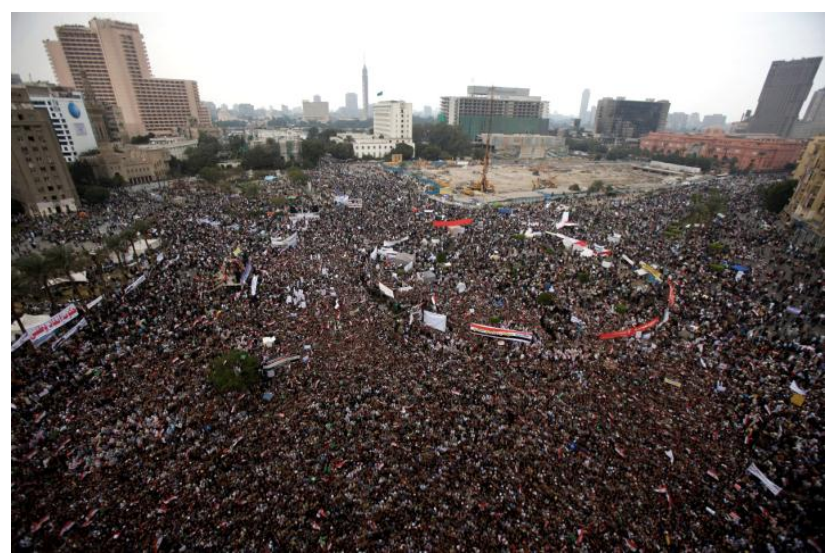

Tahrir Square, Cairo 2011

This first generation of Internet activists was also integral to the ground breaking Kefaya movement ahead of the 2005 presidential elections in Egypt, where they would blood many of the strategies used in the build-up to the 25 January 2011 protests. Yet, as may be expected with any technology-enabled phenomenon, the patterns of activists' online behaviors shifted with developments in technology.

The entrance on the scene of social media from 2007 onwards brought a new generation of Internet activists to the fore (interview with GamalEid, 2011). These activists were less interested in the long treatises on political developments that the blogger community had tirelessly created and were instead quick to act, exploiting the capability of social media for mediated mobilization. The staging of protests in 2008, in part coordinated through Face book, was a sign of things to come. By the lead-up to the 2011 demonstrations, Internet activism had come a long way in Egypt, and it was expressed in many forms » (Eaton, 2013: 7)

The Regime made a black out of Internet (Ghonim, 2012). In Alexandria, young outraged by the killing of KhaleedSaïd intoned: «We are all KhaleedSaïd ». The brutal murder of 28-year-old Khaleed Said at the hands of Egyptian police in Alexandria in June 2010s entailed outrage. His death became a cause célèbre for Internet activists. The official line that he had died while choking on a bag of drugs convinced no one. Pictures of Said have severely beaten corpse were published by the blogger. Zeinobia showed his skull and jaw with clear fractures that left the police claim that he had died of asphyxiation untenable (Zeinobia, 2010). One thousand people attended Said's funeral in Alexandria, while activists protested outside of the Interior Ministry's« (Eaton, 2013:8) Protestors exchanged information by SMS and profited of the commemoration of the police day to demonstrate in the street.

As far as uprisings in Tunisia are concerned, Tunisian young people, in the Diaspora and in the homeland, blogged and used social medias by sharing videos, comments, information's through Face book, Twitter...In 2010-11, Tunisia was high ranked in Internet use (26 per cent) in Africa.

The first digital Blogger ZouhayrYahyaoui was arrested, tortured and died in the prison by heart attack in 2005 . He first dared to criticize dictatorship of Zine El Abidine Ben Ali. The authorities strengthened and tightened their control on Internet. Many bloggers used proxy driver to protect their Internet account against cyber police control. Some youth gathered and demonstrated peacefully in white wearing's across the Information ministry to claim free access to information. The uprising had grown since Mohamed Bouazizi set himself in fire on December, 17, 2010s at his hometown SidiBouzid because a woman police agent confiscated his vegetables cart. The outrage overspread all over the country.

In contemporary society, individual matters more than traditional communities of belonging (e.g., tribes, clan, and extended family). Individual loses within crowd of uprising (Le Bon 1905). The movement becomes a collective game witnessing of awareness of change, which is leaderless. Tunisia uprisings since 2008 were more propelled more by spontaneous anger, fear, outrage against dictatorship and injustice than a previously planned project for change. 
Rubighini pointed out in this issue:

«Mohamed Bouazizi was a symbolic individual, whose meaning and intentions were crafted by others, largely after his self-immolation; he did not mobilize others directly through his decisions. His momentous decision had its amazing ripple effects only because of the work of others who crafted him into a moving emblem of resistance to corruption. Without that symbolic work he would have remained a local statistic unknown to anyone except his family, health workers, and the police. » (Rebughini 2013).

The spillover of people uprisings in Tunisia and elsewhere in the world wasn't only due to social media or information new technologies. These one are indeed «extension of man » (McLuhan, 1960) because there are corporal, sensual and emotional interaction between man and its physic environment. In fact, new media are medium, which constitutes an interface between man and his physical environment. According to Neuro Sciences works, the cognition of the physical space is determinant of the public space. Manuel Castells developed his theory on Networks society in a techno structural approach. In his recent works on social movements and networks he argued that outrage triggered street movements in Iceland, Spain, Wall Street, Tunisia, Tahrir square Egypt, Yemen, Bahrain...By his own, every individual felt scare, but when they communicate together people felt together and have hope to overcome authoritarian repression and occupy places and protest (Castells 2012)

\subsection{Emotional Movements Framed by NTIC}

Left activists, democrat's militants, worker organization unions didn't admit to be ruled by a new form of religious dictatorship. They refused to be under an authoritarianism fed by religious obedience's. Ben Ali succeeded during 23 years to scatter fear among people by police apparatus, traditional medias (radio, TV, satellites) and new wireless ones (Internet via cyber police). This is also was through state and party (RCD) organizations. It is not here room to confine our analyses of the movements to psychosocial level but emotion played a key role in the trigger of those social movements.

Referring to Neuroscience works (Damasio 2009), Manuel Castells pointed out: «In the context of the six basic emotions that have been identified by neuron-psychologists (fear, disgust, surprise, sadness, happiness, anger; (Ekman1973), the theory of affective intelligence in political communication (Neuman et al.2007) argues that the trigger is anger, and the repressor is fear. Anger increases with the perception of unjust action and with the identification of the agent responsible for the action. Fear triggers anxiety, which is associated with avoidance of danger. Manual Castells pointed out: "Fear is overcome by sharing, and identifying with others in a process of communicative action. »(Castells, 2012: 219). The contemporary social movements are transnational. Valentine Moghadem pointed out: "world-system analysis contributes to our understanding of where democratic transitions take place and when. Democratic transitions have been concentrated in semi peripheral or peripheral countries indeed, a country's core, semi peripheral, or peripheral positioning the world-system may shape the rate and quality of democratic growth. Democratic movements and polities are less likely to be found in peripheral countries that are disadvantaged economically, unable to access global resources, and devoid of large middle classes or control may undermine efforts by social movements or their leaders to effect positive social change."(Moghademet al.2013: 66)

New wireless social media succeed, somehow, to bring people together. Wolf argues in this issue: «At this point, in its evolution, it appears that the Internet serves only to equalize the differences among young college-educated, middle-class, white males. » (Cited by Cathrine Helen Palczewski, 2001 : 169)

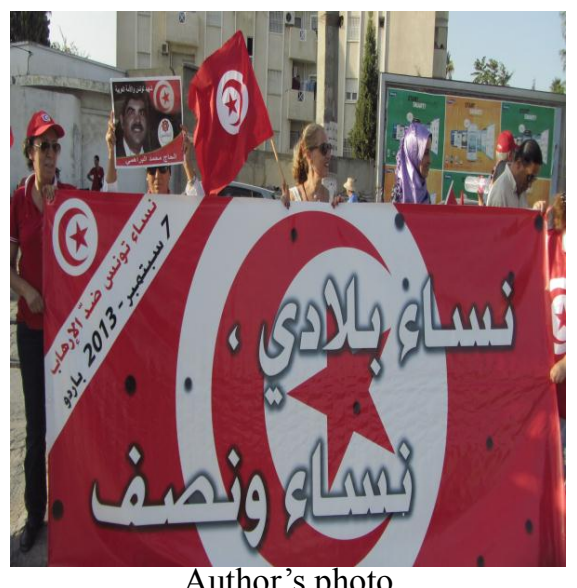

Author's photo

Tunisian women marche in Bardo, September, 7, 2013 Against Terrorism

'My country's ladies are women and half' 
In the Human Development Report of 2013, the Gender Inequality Index ${ }^{3}$ was 2.61. Tunisia is ranked in this issue in 46 amongst 148 countries surveyed within the GII. Women concerns in modern Tunisia are healthcare reproduction, recognition as full citizens, equal distribution of economic growth returns, and empowerment, and an equal share of parliamentary seats by each gender.

«Women have traditionally been disadvantaged in the political arena at all levels of government. To capture this disadvantage, the Gender Inequality Index (GII) uses the ratio of female to male representatives in parliament. National parliamentary representation, which reflects women's visibility in political leadership and in society more generally, has been increasing over time, even though the global average is still only $16 \%$. In 2008 Tunisia's parliament became the first to have a majority of women; women hold $19.9 \%$ of all parliamentary seats, and Egypt has the least representation of women, at $3.7 \%$.

Women's representation in parliament is less than 10\% in seven out of ten countries. » (El Laithy, 2012)

«Among one 100.000 live births, 56 women die from pregnancy related causes, and the adolescent fertility rate is 4.4 birth per 1000 live births. As far as economic participation is concerned, women rates in labor market are about 25.5 percent compared to 70 for men.

Alain Touraine tried to argue in his book entitled «Le Monde des Femmes » how post feminist movements in France and in the modern world care about women subjectivity «I am a Woman». If Marxism highlighted on women condition within class struggle and socio economic rights both for two genders, the women movements struggled for equity in civil rights and participating in decision-making alongside men. They are, also, fighting against patriarchal representations-dominant in modern societies- of women being. Touraine referred to Regis Debray comments on the controversies between republicans and democrats. Women movements support democracy. The modern post-feminism tend to give priority to civil society movements and mainly to their own private lives against a political universe more and more disconnected of lived world, but interpretative discourses confer to politics an absolute priority. » (Touraine, 2006:189)

For example, the International Federation for Human Rights suggests: "recent history painfully reminds us that the massive occupation of public space by women during the revolution, in no way, guarantees their role in the political bodies of the regimes that follow." Instead, the Federation continues, "although the situation of women varies across the region exclude them from public life." (Cited by Laura Sjoberg et al., 2011)

Although some argue that the virtual world allows for the dissipation of the impact of discrimination linked to physical characteristics because of the lack of actual face-to-face communication, the reality is that discrimination continues, albeit in a masked form. In fact, Studies of the Internet contest its ability to function as 'the great equalizer'." Wolf (1998) argues: "At this point in its evolution it appears that the Internet serves only to equalize the differences among young, college-educated, middle-class, white males" (30)

Indeed Information and NTIC have the merit to shorten distances physically between people a worldwide, and allowed horizontal communication often out control of top authority and its censorship power. They fostered togetherness, nearness and otherness (Castells 2006, 2012) in day-to-day life. They, in the same time posit the question of its lacking of face-to-face contact. They could, also, contribute to the deepening of social, regional, and international economic, cultural inequalities. The haves are better connected to information than are the have-nots. This privilege twined with the high ranked economic and social position in society perpetuates and reinforces social inequalities. In a case study on 'regional inequality of education in Tunisia', SalwaTrabelsi argued:

"The results prove that the gap between men and women, in terms of educational inequality and of the average years of study were maintained between the years 1975 and 2004. The educational Gini index realized a decrease for both sexes and for all regions but it is higher for female compared to male in all regions particularly in the Center West where inequality is the highest." (Trabelsi, 2013: 110)

Both in Tunisia and Egypt 'presidentialistic' dictatorships put low hand on medias (TV, Radio, Newspapers, arts, literature, Internet), and allowed only information's broadcast that doesn't threaten their politic authorities. Moreover, the spillover of fear among people constrained many to be obedient to its hegemony, which entailed obedience and subjugation to the ruler (Hibou 2006; Geisser and Camau 2003; Foucault 1984 to cite but a few). The latter explained it as a 'Tunisianity' phenomenon. Though, Tunisian people made its revolution against Ben Ali authoritarian and corrupted regime.

In the aftermath, of Arab uprising, democratic processes succeeded in Tunisia where Islamists and secularists made a consensus and achieved a new constitution drafting which guarantees civil rights and freedoms within a Muslim and Arab society opened to universal values. If social movements after the revolution focused on struggling against Troika

\footnotetext{
${ }^{3}$ The Gender Inequality Index is based on: reproductive health measured by maternal mortality and adolescent fertility rates, empowerment is calculated by the share of parliamentary seats held by each gender and secondary and higher education attainment of each gender, Economic activity is measured by the labor market participation rate for each gender.
} 
ruling parties led by the main party Ennahdha, the ongoing social movements trigger the sustainable development challenges (Youth unemployment, social injustices and inequalities, and Education reforms).

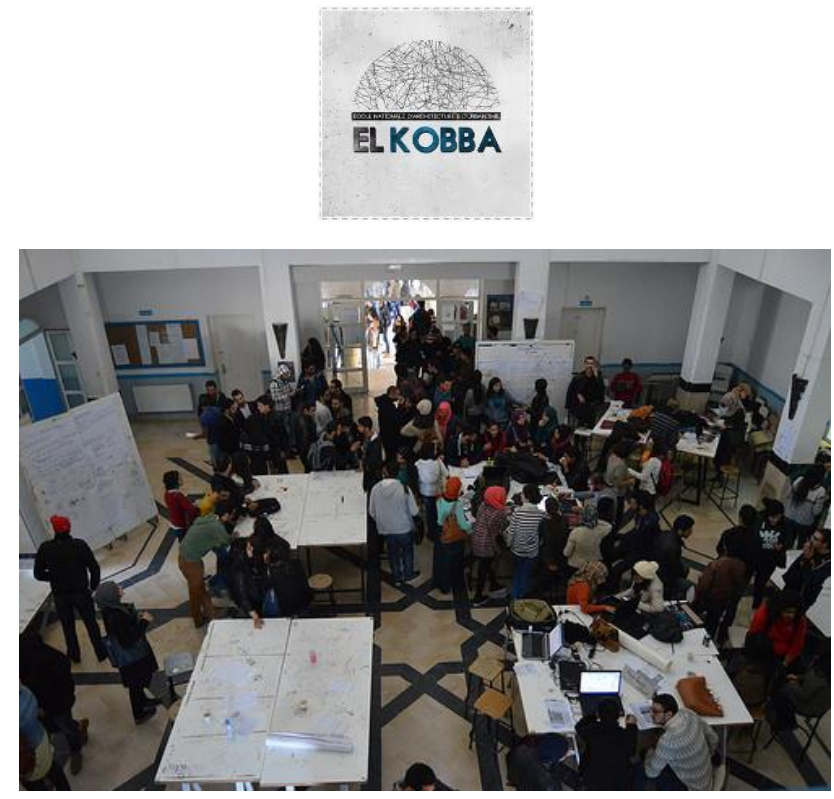

http://www.tunisia-live.net/2014/11/14/occupy-el-kobba-enau-students-call-for-reform/

Occupy at National School of Architecture and Town Planning in Tunis, November, $7^{\text {th }}, 2014$

The El Kobba Movement started in November $7^{\text {th }} 2014$ until the end of the month. Architecture students protested against a suffocating teaching system and claimed new reforms for more student's participations and fairness in evaluating their skills.

Thus, the new public sphere becomes more and more shaped by wireless social Medias. Mohamed Kerrou argued in this issue: «this new public and media sphere doesn't match with the ancient public sphere centered on the obedience of the ruled people to the ruler, to the state-party and to the personality cult serving to the infinite prolong of presidents terms and covering the abuses and the financial embezzlements of Ben Ali personally and his relatives. »(Kerrou, 2012: 219)

Though, Tunisia was ranked amongst the most performing economies in Africa. (AFDB $\left.{ }^{4}, 2011\right)$. The economic growth didn't correlate with human rights respect by the regime. A doubtful mafia had grown around Ben Ali relatives and committed many human rights abuses. The democratic transition process is facing economic developments challenges.

\section{Conclusion Remarks}

Modern social movements in the Arab countries are not disconnected to social movements worldwide. Whenever in Tunisia, Egypt, Yemen, Algeria, Bahrain...people stood up against authoritarianism exerted upon them by monarchies or 'presidentialistic' regimes, which had been ruling countries during long periods (Libya 42 years, Egypt Mubarak, 25years, Tunisia Ben Ali, 23 years....) (Moalla, 2014:38). Those protests, in 'Arab countries, were neither propelled by ideologies, or religions nor by leaders, and opposition political parties.

Myriad of economic, social, psychological, and political factors played key roles in triggering those protests and uprisings. In Tunisia, the process begun far back to 2008 miner's basin clashes which erupted due to unjust recruiting in SfaxGafsa Phosphate Company in Redayef, Moulares, Mdhilla miner villages of Gafsa governorate in the south western Tunisia. Moreover, the Ben Ali decision of imposing a tax on informal traders between Libya and Tunisia in the Border area of RasJdir in Ben Guerdane in the south eastern Tunisia unclenched protests among local population living broadly thanks to informal commerce with Libya, Mohamed Bouazizi Self immolation in December, $17^{\text {th }}$, 2010s nearby SidiBouzid Governorate headquarter was somehow the tree which hide the forest of anger growing among Tunisian population. In January, 14th, 2011, crowd of protestors gathered in HabibBourguiba Avenue crying “Dégage!'(Get away!) toZine al Abidine Ben Ali. He fled the country to Saudi Arabia Kingdom.

In Egypt, the kefaya movement which sparked in 2005, the workers strike in April, 7, 2010s, the WajdiGhonim arrest, and killing by Hosni Mubarak regime in the police day festivities entailed the growing of protests in Cairo, Alexandria... The movements of cyber bloggers Dywannya defied authorities, which imposed a black out on Internet. Cyber activists used SMS messengers to communicate and overcome cyber police control. 25 February 2011 more and

4 African Development Bank 
more protestors gathered in Tahrir square and Egyptian people succeeded to step down the authoritarian regime of Hosni Mubarak. Both movements were crowned by the collapse of the regime, but only Tunisia succeeded till yet to achieve a democratic transition.

The social movements in the so called Arab Spring are social because of the growing social inequalities between the best well off who benefitted of economic policies led by former authoritarian regimes and the less well off who were left behind by those unfair policies. Those excluded categories felt scornfully oppressed, marginalized, disdained (in Tunisian dialed Al Hogra ) constituted one emotional stressor that triggered outrage. The feelings of anger, sadness, stress, and despair found home in New Technologies of Information and Communication (NTIC). The wireless network played a key role in sharing information by bloggers in Diaspora and in Tunisia. Many young people overcome the wall of fear and occupied places (HabibBourguiba Avenue in Tunis, Tahrir Square in Cairo...). In fact, emotions and NTIC were main factors in triggering protests. Wireless media (Face book, Tweeter), and civil society networks were the main actors of those movements. The success of the democratic process in Tunisia doesn't mean the end of social movements. The new democratic institutions of Tunisian state face the terrorism threat which denies state and democracy.

The latter encompass opposition right to express and to be organized. Civil society constitutes globally and locally new counter powers against possible deviation toward dictatorship. Economic, Social and cultural changes fuelled and propelled new social movements which target benevolently or malevolently state institutions. Social movements are a continuous process propelled by actors of civil society and constitute a network counter power against regime hegemony on society locally and globally. New social movements contribute to social change by affecting state institutions positively or negatively. Finally we could prospect that new social movement would grow and develop in the way to evoke the sustainable urban and social development of Tunisia and its regional neighborhood.

\section{References}

Amin, A. (2006). Collective Culture and Urban Public Space. http://www.publicspace.org/en/text-library/eng/b003-collective-culture-and-urban-public-space

Robert, A., \& Daniel, C. (2001). Counter Public and the State, Robert Sunny Press, State University of New York, 279. http://rhetorics-of-social-change.wikispaces.com/file/view/Cybermovements\%20Palczewski.pdf/264071909/Cyber movements\%20Palczewski.pdf accessed on Wednesday, March 02nd, 2014 at 17:01

Belkhoja, A., \&Cheikhrouhou, T. (2013). 14 Janvier, L'Enquête, AppolinaÉditions, 191

Benhabib, S. (1992). Situating the Self: gender, community, and postmodernism in contemporary ethics, New York: Psychology Press, 266 pages

Benhabib, S. (2003).The Reluctant Modernism of Hannah Arendt. http://books.google.tn/books?id=f317SZTK4YC\&pg=PA199\&lpg=PA199\&dq=hannah+arendt+habermas\&source $=$ bl\&ots=QnCD5xOump\&sig=bygVVb99iA4FZ0Hf1XQCjRzN $\mathrm{Zk \& hl=fr \& sa=X \& ei=IwYVUKjSA8KphAeNv4HQBg \& ved=0CDEQ6wEwAA \# v=onepage \& q=hanna}$ $\mathrm{h} \% 20$ arendt\%20habermas\&f=false accessed on Sunday, July 29th, 2012 at 10:52

Benhabib, S. (2004). Reclaiming Universalism, Negotiating Republican Self-determination and Cosmopolitan Norms, The Tanner Lectures on Human Values, delivered at University of California, Berkeley, March,14-19.

Benhabib, S. (2012). The Arab Spring: Religion, revolution and the public sphere en PDF http://www.eurozine.com/articles/2011-05-10-benhabib-en.html.

Ben Romdhane, M. (2010). Tunisie, Etat, EconomieetSociété: ressourcespolitiques, légitimation, régulationsociale. Tunis: Sud Editions, 310

Bourdieu, P. (1991). Language and Symbolic Power, New York: Harvard University Press, 302.

Bourdieu, P. (2013). Distinction: A Social Critique of the Judgment of Taste, London: Routledge, 640.

Bourdieu, P. (1991). Language and Symbolic Power, New York: Harvard University Press, 302.

Bourdieu, P. (2013). Distinction: A Social Critique of the Judgment of Taste, UK: Routledge, 640.

Calhoun, C. (1992). Habermas and the Public Sphere, London: Massachusetts Institute of Technology, 512

Camau, M., \&Geisser,V.( 2003). Le syndrome autoritaire: politique en Tunisie de Bourguiba à Ben Ali. Paris: Presses de Sciences Po., 372.

Castells, M. (2009). Communication and power, London: Oxford University Press, 590pages

Calhoun, C. (1992). Habermas and the Public Sphere, London: Massachusetts Institute of Technology, 512

Camau, M., \&Geisser,V. (2003). Le syndrome autoritaire: politique en Tunisie de Bourguiba à Ben Ali. Paris: Presses de Sciences Po. 372

Castells, M. (2009). Communication and power, London: Oxford University Press, 590pages 
Castells, M. (1983). The City and the Grassroots: A Cross-Cultural Theory of Urban Social Movements, University of California Press, 450 pages

http://books.google.tn/books?id=rUbZLcYsA_QC\&pg=PA318\&dq=social+movements+cities\&hl=fr\&sa=X\&ei=ppVu U8rJDKuX0QXRjoCwDA\&ved=0CDIQuwUwAA\#v=onepage \&q=social\%20movements\%20cities\&f=false

Castells, M. (2011) The Power of Identity: the information age, U.S.A:John Wiley \& Sons,584. http://books.google.fr/books?id=19asXV40MegC\&printsec=frontcover\&dq=The+power+of+identity+castells\&hl= fr\&sa $=$ X\&ei $=9 \mathrm{DVuVJmuCMHiaomSgPAC} \& v e d=0 \mathrm{CC}$ QuwUwAA\#v=onepage $\& \mathrm{q}=$ The $\% 20$ power\%20of\%20ide ntity\%20castells\&f=falseretrieved on Thursday, 20 November, 2014 at:19: 43

Castells, M. (2012). Networks of Outrage and Hope Social Movement in the Internet Age, Cambridge: Polity, 298pages

Chaeb, D. T., \&Ben, T. (2013). Les Nouveaux Espaces de Communication Virtuelle: le cas de Face Book, In: Les Espaces Publics au Maghreb, Tunis:Dirasset et Oran: Centre de Recherches en AnthropologieSociale et Culturelle, 397pages in French et 208 pages in Arabic, 351-366.

Clark, E. (2014).Social Movement and Social Medias http://www.diva-portal.org/smash/get/diva2:539573/FULLTEXT01.pdf

Chomsky, N. (2012). Occupy, London: Penguin Book Ltd, 121. Counter power as common power In: The Journal of Aesthetics and Protests. http://www.joaap.org/issue9/notanalternative.htm

Daoud, A., \& La RévolutionTunisienne(2011). Lecture par le déséquilibre du territoire. http://data7.blog.de/media/396/5904396_2ac85e8809_d.pdf

Davidson Richard et al. 2000s. Emotion, Plasticity, Context, and Regulation https://psyphz.psych.wisc.edu/web/pubs/2000/Emotion_Plasticity.pdf

Donatella, Della Porta and Mario, Social Movements: an Introduction (2014).http://www.hse.ru/data/2012/11/03/1249193172/Donatella_Della_Porta_Mario_Diani_Social_Mov.pdf retrieved on Friday, May, 2nd, 2014 at 13:43

Jean-Pierre, D. (1992). Introduction aux Sciences Sociales: logique des phénomènesCollectifs, Paris: Edition Marketing, 297 pages

Fraser, N. (1990). Rethinking the Public Sphere: A Contribution to the Critique of Actually Existing Democracy,

http://api.ning.com/files/hRwSaOzKhGD-wGyDZuJeNffJvQrETo9IizI7bNRisAQ_/RethinkingthePublicSphere.pdf accessed on Monday, April 14, 2014

Source: Social Text (1990), Duke University Press, 25-26, 56-80. http://www.jstor.org/stable/466240

Fraser, N. (2013). Fortunes of Feminism: From State-Managed Capitalism to Neoliberal Crisis, Verso Books, 24,256. http://books.google.tn/books?id=NYBCVV3gL5gC\&printsec=frontcover\&hl=fr\#v=onepage\&q\&f=false

Foucault, Ml. (1984). SurveilleretPunir: Naissance de la Prison, Paris: Editions Gallimard, 340 pages.

Gana, Nouri et al. (2013). The Making of the Tunisian Revolution: Contexts, Architects, Prospects, New York: Edinburgh University Press, Ltd, 340pages

Giddens, Anthony (2013) the Third Way: The Renewal of Social Democracy, London: John Wiley \& Sons, 176pages

Ghonim, Wael. (2012). The Revolution 2.0: the power of is greater than the people in the power, Library of Congress Cataloging-in-publication data, New York Houghton Mifflin Harcourt, - 308 pages

Hibou, B. (2006). La Force de l'obéissance: Economiepolitique de la répression en Tunisie, Paris: La Découverte, 363

Habermas,J. (1991). The Structural Transformation of the public Sphere, USA: MIT Press, 301p (This work originally appeared in German under the title "Structurewandel der offentlichkeit, 1962, Hermannluchterhand Neuwied", Federal Republic of Germany)

Hamdi A. H. (2010). Civil Society and Democratization of the Arab world http://www.csduppsala.uu.se/devnet/CivilSociety/Outlookserien/2010,PowerPeople/PP,\%20Hassan,\%20Hamdi\%20A.pdf

IbnKhaldûn, Abdurrahmane. (1969). An Introduction to History,Trans. FromArabic by Franz Rosenthal, edited and abridged by N.J. Dawood, Bollingen Series, West Sunex: Princeton UniversityPress.465

Jaspers, James and Jeff Goodwin. (2006). Emotions and Social Movements.

http://www.jamesmjasper.org/files/Final_Proofs.pdf

Joel Beininet Frederic Vairel. (2011). Social Movement Mobilization, and Contestation in Middle East and North Africa, Stanford University Press, 308.

http://graduateinstitute.ch/files/live/sites/iheid/files/sites/international_history_politics/shared/history_course_supp ort_2013-2014/HI021/Beinin\%20Vairel\%20Social\%20movements\%20-\%20introduction.pdf accessed on Monday, 
March, 24, 2014

John Davis. (2013). The Arab Spring and Arab Thaw: Unfinished Revolutions and the Quest for Democracy, Ashgate Publishing.

http://books.google.fr/books?id=WU6iAgAAQBAJ\&dq=sjoberg+arab+spring+women\&hl=fr\&source=gbs_navlinks_s

Jeff Goodwin, James M. Jasper. (2009). The Social Movements Reader: Cases and Concepts Oxford: John Wiley \& Sons- 458.

Kerrou, M. (2012). les Nouveaux Acteurs de la Révolution et de la transition politique, IN: La transition démocratique en Tunisie, Etat des Lieux, L'ObservatoireTunisien de la transition Démocratique, Diwen Edition, 17-234

Kevin Lewis et al. (2014). The Structure of Online Activism.

http://www.sociologicalscience.com/download/volume\%201/february_/The\%20Structure\%20of\%20Online\%20Ac tivism.pdf

Klandersmans, B.,\&Staggenborg, S. (2002). Methods of Social Movement Research, Universityof Minnesota Press, 382 pages

http://books.google.fr/books?id=ExVgY9i53B4C\&printsec=frontcover\&hl=fr\&source=gbs_ge_summary_r\&cad=0\#v= onepage \&q\&f=false

Le Bon, Gustave. (1905). Psychologie des Foules, Paris: Édition Félix Alcan, 9e édition, 192 pp.

Mac Nally. (2013). Marxism and Social Movements, edited by Colin Barker, Laurence Cox, John Krinsky and Alf Gulvald, BRILL,482pages http://books.google.fr/books?id=uF2Fz_OuHH0C\&printsec=frontcover\&hl=fr\#v=onepage\&q\&f=false

Marx, K.,\&Engels, F. (2002). Le Manifeste du PartiCommuniste 1948, Uneéditionélectroniqueréalisée à partir du livre de Karl Marx et Friedrich Engels, Manifeste du Particommuniste. (1848) Traductionfrançaise, 1893 par Laura Lafargue. Edition complétée le 2 avril 2002 à Chicoutimi, Québec.

National School of Architectureand Town Planning, Occupy El Kobba, StudentsStrikesMovement, Tunis.http://www.tunisia-live.net/2014/11/14/occupy-el-kobba-enau-students-call-for-reform/

Rohmer Elizabeth et Abraham Moles. (1978). Psychologie de l'Espace, Paris: Casterman, coll. SynthèsesContemporaines, Vol 21 de Synthèsescontemporaines, 245 pages

Tarde, Gabriel. (1901). L'Opinionet la Foule, Uneéditionélectroniqueréalisée à partir du livre de Gabriel Tarde, L'Opinion et la foule. Paris: Les Presses universitaires de France, 1989, 1re édition. Collection Recherchespolitiques, $184 \mathrm{pp}$. Celivre a étéoriginalementpublié pour la première fois en 1901. 102. http://classiques.uqac.ca/classiques/tarde_gabriel/opinion_et_la_foule/tarde_opinion_et_la_foule.pdf retrieved on Thursday, December, 11, 2014 at 9:12

Trabelsi, S. (2013). Regional Inequality of Education In Tunisia: An Evaluation By The Gini Index.http://region-developpement.univ-tln.fr/fr/pdf/R37/5_Trabelsi.pdf

Valentine M. M. (2012). Globalization \&Social Movements, Rowman\& Littlefield Publishers, 82.http://books.google.fr/books?id=HT5iKaIcTV4C\&printsec=frontcover\&hl=fr\#v=onepage \&q \&f=falsehttp://boo ks.google.tn/books?id=JSdstTJWNq4C\&printsec=frontcover\&dq=the+révolution+2.0+wael+ghonim\&hl=fr\&sa= $\mathrm{X} \& \mathrm{ei}=\mathrm{TClBU} 5 \mathrm{H} 5 \mathrm{O} 46 \mathrm{YhQfvv} 4 \mathrm{DICQ} \& \mathrm{ved}=0 \mathrm{CC} 4 \mathrm{Q} 6 \mathrm{AEwAA \# v}=$ onepage \&q=the\%20révolution\%202.0\%20wael $\% 20$ ghonim\&f=falseaccessed on Sunday,

Laura S.,\&Whooley, J. The Arab Spring for Women? Gender Representation and Middle East. http://www.polisci.wisc.edu/Uploads/Documents/IRC/Sjoberg.pdf accessed on Saturday, April 19, 2014 at 6: 44

MihoubSamia, Le cyber activisme à l'heure de la revolution. http://archivesic.ccsd.cnrs.fr/docs/00/67/84/40/PDF/cyberactivisme.SMihoub.publiA_.pdf accessed on Saturday, May 3d, 2014 at 9: 23

MiloubSamia-Drame. (2006). Internet dans le monde arabe Editions L'Harmattan, 330 pages

Moalla, M. (2014). Gouverner :esquisse en conclusion d'un Nouveau Modèle de développement pour la Tunisie, Tunis : Edition SNIPE-La Presse- Essahafa al Yaoum, SociétéNationaled'Impression, de Presse et d'Edition, 416.

Redissi, H., Nouira A., \&Zghal A. et al. (2012). La Transition Démocratique en Tunisie, Etat des Lieux, Les Acteurs, Tuni: Diwen Editions, 368 pages

La Transition Democratique en Tunisie, Etat des lieux, Les Thématiques, Tunis: Diwen Edition, 190pages

Valentine M. M. (2012). Globalization \&Social Movements, Rowman\& Littlefield Publishers- 282.

The role of social media in the Arab uprisings - past and 
present.https://www.westminster.ac.uk/_data/assets/pdf_file/0004/220675/WPCC-vo19-issue2.pdf accessed on Sunday, March 9, 2014 at 10: 39

Spiers,H. J.,\&Maguire, E. A. (2007). Review the Neuroscience of Remote Spatial Memory: a tale of two cities

Neuroscience 149 (2007) 7-27 Welcome Trust Centre for Neuro imaging, Institute of Neurology, University College London, 12 Queen Square, London WC1N 3BG, UK

Pat. G. Coy. (2013). Research in social movements, Conflicts, and Changes Emerald Group Publishing,311 pages.http://books.google.fr/books?id=hSnlKTF-bF0C\&dq=social+movement+inequalities+social $\& \mathrm{hl}=$ fr\&source=gbs_navlinks_s accessed on Monday, March, 24, 2014 at 08:14

Rahou, Y. (2013). Les Femmes dansl'EspacePublique: unenjeu de politiquespubliques, In Les Espaces Public au Maghreb, Tunis Dirasset et Oran: Centre de Recherches en AnthropologieSociale et Culturelle, 397pages in French et 208 pages in Arabic, 251-261

Remaoun, Hassan etHeniaAbdelmajid. (2013). Les Espaces publics au Maghreb, Tunis Dirassetet Oran: Centre de Recherches en AnthropologieSociale et Culturelle, pages in French et 208 pages in Arabic

Sassan, S. (2013). The Global City New York, London, Tokyo, New Jersey: Princeton University Press, 480 pages

Tarde, G. (1901). L'Opinion et la Foule, Un document produit en version numérique par Jean-Marie Tremblay, bénévole, professeur de sociologie au Cégep de Chicoutimi, 102.http://pages.infinit.net/sociojmt

Dans le cadre de la collection, Les classiques des sciences sociales, http://www.uqac.uquebec.ca/zone30/Classiques_des_sciences_sociales/index.html

Weber, M. (1978). Economy and Society: an outline of Interpretative Sociology, 1, California: University of California Press, 1470.pages

https://books.google.fr/books?id=pSdaNuIaUUEC\&printsec=frontcover $\&$ hl=fr\#v=onepage \&q\&f=false retrieved on Thursday, December, 11th, 2014 at 10:00

Wynne, A. (2011). North African Revolt against new public management as well as for democracy. http://www.icgfm.org/journal/2011/no1/2011-part9.pdf retrieved on Tuesday, May, 13, 2014 at 6:20

Zghal, A. (1982). Note pour un débatsur la jeunesse arabeIN :Actes du Colloquejeunesse et changement social : Tunis, 8-13.Novembre 1982. Cahier du C.E.R.E.S., Sériesociologique no.10, 36pages

Zine, M. C. (2013).L'Espace Public maghrébindans la France d'aujourd'hui, le regard d'un intellectuelfrançais Michel de Centeau, In: Les Espaces Publics au Maghreb, Tunis Dirasset et Oran: Centre de Recherches en AnthropologieSociale et Culturelle,(dir.) Remaoun Hassan et HeniaAbdelmajid, 79-91

\section{(cc) $\mathrm{Br}$}

This work is licensed under a Creative Commons Attribution 3.0 License. 